It is proved that in order to achieve high and qualitative results in the field of providing educational products, higher education institutions are obliged to be aimed at the service market in the society in time. The fulfillment of such tasks, in its turn, requires appropriate methodological and logistical support of the educational process in the higher education institution; highly qualitfied scientific and pedagogical staff; monitoring and periodic updating of educational programs; annual assessment of the professional competence level of higher education applicants, scientific-pedagogical and pedagogical employees of higher education institutions and regular publication of the results of these assessments; ensuring the training of pedagogical and scientific-pedagogical staff, ensuring the availability of the necessary resources to organize the educational process for each educational program; providing and keeping public information on educational programs; ensuring the availability of information systems for effective management of the educational process; ensuring academic integrity by employees of higher education institutions and students, etc. It is also noted that the reforms of the higher education, caused by challenges posed by society, do not provide additional sources of funding to meet the mentioned above objectives. Therefore, there is an urgent and acute need to implement a qualitatively new approach to the implementation of a management system in the field of modern educational services with the available resources.

Planning the educational process is a must and one of the most significant links of the activities of higher education institutions. When planning the educational process, it is necessary to take into account the diversity of activities of the teaching staff namely the teaching load performance, carrying out scientific, educational and methodical work, advanced training, vocational work and other activities. Taking into account the available resource potential of higher education institutions, including materiel and technical support and software resources, the author has introduced the technology of using the Microsoft Office suite, which includes software for working with different types of documents: texts, spreadsheets, presentations, databases etc. and the Google Docs Network Office suite.

The introduction of the described technology will make it possible to increase the efficiency of using the resources of the higher education institution by informatising the educational process planning management, in particular by the example of the development and implementation of the curriculum pattern. The curriculum is one of the basic units of organization and planning of the educational process, it requires the greatest effort in process of the the correct and logical construction.

The author has designed and described a curriculum pattern using Microsoft Excel that would minimize the time and process involved in designing the curriculum. An algorithm of filling the submitted curriculum pattern is presented in the study.

Completely developed curriculum with all the fields filled in, allows to develop and form working curricula, the amount of study load can be calculated on their basis in the departments and faculties.

The introduction of such a pattern of the curriculum will further facilitate the work on the formation of the diploma and the supplement to the diploma of the European sample of each university graduate.

Its efficient, logical and consistent organization will help to create favorable working conditions for each participant of the educational process, facilitate the diverse interaction of the managing and managed system of the higher education institution.

Key words: informatization; management informatization; planning; curriculum; educational process schedule; educational load; educational process; higher education institution

Стаття надійшла до редакції 24.10.2019 р.

УдК [37:316.752]:378.04

DOI: https://doi.org/10.33989/2075-146x.2019.24.194599

\title{
РЕНАТА ВИННИЧУК
}

ORCID ID 0000-0002-1508-7984

Полтавський національний педагогічний університет імені В. Г. Короленка

\section{ПЕДАГОГІЧНА АКСІОЛОГІЯ У КОНТЕКСТАХ ГУМАНІТАРНОЇ ПРОФЕСІЙНОЇ ОСВІТИ}

\begin{abstract}
У статті розкрито тлумачення педагогічної аксіології у контекстах гуманітарної професійної освіти як сучасного наукового напряму пошуку цивілізаційних орієнтирів професійного розвитку особистості фахівця. 3'ясовано в ході характеристики педагогічної аксіології, як науки про цінності, поняття ціннісних орієнтацій, їхньої структури і класифікації, можливі шляхи розвитку аксіосфери особистості в гуманітарній професійній освіті, що з аксіологічної точки зору в межах системної методології освіту розглядають як багаторівневий простір, один із визначальних чинників суспільства, який відіграє активну соціально-ціннісну роль, а в рамках постнекласичної наукової парадигми - наполегливо актуалізує аксіологічні аспекти буття людини (загальнолюдські і професійні цінності та відповідні ціннісні орієнтації й ідеали). Українські вчені (педагоги, психологи, філософи та ін..) особливої уваги надають дослідженню ціннісних парадигм професійної освіти в контекстах євроінтеграції, забезпеченню свободи вибору системному баченню сукупності гуманітарних освітніх цінностей.
\end{abstract}

Ключові слова: педагогічна аксіологія; гуманітарна освіта; загальнолюдські цінності; професійні цінності; ціннісні орієнтації; ціннісний шар свідомості

Постановка проблеми. Актуальність формування загальнолюдських і професійних цінностей студентської молоді нині обумовлена низкою чинників, зокрема, сучасним станом українського суспільства, коли в умовах існування гострих проблем його духовного оздоровлення й відродження відбувається інтенсивний пошук

(C) Р. Вінничук, 2019 
цивілізаційних орієнтирів розвитку. Метою діяльності вищих закладів освіти є професійна підготовка фахівців через призму загальнолюдських гуманістичних цінностей: ідеалів добра, правди, краси, справедливості, совісті, людської гідності та реалізація місії українського національного виховання через прищеплення молодій людині відданості цим ідеалам. У зазначеному контексті першочергово постає проблема модернізації змісту університетської гуманітарної освіти, що має органічно поєднувати різнопланові особистісно й соціально відповідні аксіологічні аспекти.

Аналіз досліджень і публікацій. Постнеокласична наукова парадигма, що співвідноситься 3 поняттям «сучасний освітній простір», як одну з базових характеристик освіти наполегливо актуалізує аксіологічні аспекти буття. Саме в освітньому контексті цінності вважають гранично загальною ідеєю, що надає освіті сенсу; таким чином, учені не лише осмислюють проблеми освіти, а й створюють сучасний освітній простір, підкреслюючи його діалогічність на рубежі XX-XXI століть. Діалог світових культур та суперечності між ними розглядають Т. Григор'єва, В. Топоров; проблеми стилю мислення, менталітету як основи педагогічних поглядів вивчають П. Гайденко, В. Губін, І. Новік, у зарубіжній філософії науки - Д. Агассі, Т. Кун, І. Лакатос, А. Маслоу, П. Фейєрабенд та ін. Діалоговий характер освітньої практики як специфічної людської діяльності знайшов відображення в роботах О. Брудного, О. Огурцова, С. Розової, В. Шадрикової та ін. Вітчизняна історіографія проблеми цінностей в освіті представлена працями сучасних українських дослідників В. Андрущенка, В. Крижка, I. Предборської, О. Сухомлинської, Н. Ткачової. Проблема цінностей в освіті в україномовному філософському просторі стала предметом досліджень Н. Іордакі, С. Клепка, М. Култаєвої, В. Огнев’юка та ін.

Вивчення проблеми професійних цінностей переважно пов'язують 3 дослідженням та уточненням специфіки особистісного розвитку. Зміст понять «цінності» й «ціннісні орієнтації» вчені вивчають у філософському (В. Василенко, І. Зязюн, М. Каган, В. Кремінь, М. Шелер), психологічному (К. Абульханова-Славська, Л. Виготський, О. Леонтьев, А. Маслоу) та педагогічному (Т. Бутківська, О. Вишневський, В. Давидов, А. Мудрик, Н. Никандров, Ю. Орлов, В. Сластьонін, В. Струманський, О. Сухомлинська, Н. Ткачова та ін.) аспектах. У психолого-педагогічних дослідженнях часто використовують поняття, подібні за змістом до цінностей і ціннісних орієнтацй: особистісний сенс (О. Леонтьев), установка (Д. Узнадзе), ставлення (В. М'ясищев), ціннісні орієнтації (В. Ядов), спрямованість чи внутрішня позиція особистості (Л. Божович), метамотиви (А. Маслоу).

Ознайомлення з результатами теоретичних напрацювань учених, практичним досвідом підготовки студентів у вищих навчальних закладах дало змогу виявити низку суперечностей між: потребою у вихованні активної особистості, здатної регулювати власну діяльність, оволодівати системою цінностей, знань і вмінь та низьким рівнем сформованості такої активності у випускників вищих закладів освіти; запитом суспільства на творчу особистість та недостатньою розробленістю педагогічних технологій формування готовності майбутніх фахівців до саморегуляції власної діяльності на засадах системи професійних цінностей і ціннісних установок.

Тому метою цієї розвідки постає характеристика педагогічної аксіології як науки про цінності, поняття ціннісних орієнтацій, їхньої структури і класифікації, можливих шляхів розвитку аксіосфери особистості в гуманітарній професійній освіті.

Виклад основного матеріалу. Сучасний стан розвитку суспільства та освітньої галузі актуалізує проблему цінностей, стимулює їх переоцінку й осмислення. «Те, що зовсім недавно сприймалось як непохитні канони, зазначає Л. В'язнікова, - тепер викликає сумніви в його значущості й доцільності» (Вязникова, 2002). За словами Д. Леонтьєва, нині часто спостерігаємо «ціннісний нігілізм, цинізм, метушню у виборі цінностей, екзистенційний вакуум та багато інших симптомів соціальної патології, яка виникла на грунті зламу ціннісної основи, смислового голоду й вивиху світогляду» в посткомунікатичних обставинах (Леонтьев, 1996, с. 15). Це призводить до кризи не тільки соціальної, але й професійної; як наслідок відбувається деформація самосвідомості, відчуження особистості від власної професійної діяльності, відповідно, виникає соціально значуще завдання істотного оновлення цінностей освіти.

Основи аксіологічних ідей в освіті розроблені вченими В. Андрущенком, Л. Губерським, М. Михальченком, I. Предборською та ін. (Андрущенко, 2008; Губерський, Андрущенко, \& Михальченко, 2002; Андрущенко, \& Предборська, (Ред.) 2009). У працях цих дослідників фундаментально проаналізовано сутність аксіології як науки про цінності, поняття ціннісних орієнтацій, їхньої структури й класифікації, а також можливі шляхи розвитку аксіосфери особистості в освіті, доведено, що ціннісні орієнтації мають об'єктивно-суб'єктивний характер і водночас $є$ культурним продуктом розвитку власне особистості.

У кінці XX - на початку XXI століть питання про інтерпретацію аксіологічних ідей освіти стає принциповим при формуванні стратегії розвитку системи освіти України. Сучасна система освіти, за висловлюванням П. Щедровицького, «дісталася нам у спадок від Радянського Союзу, на жаль, не має аксіологічної ідеї» (Щедровицкий, 1998). Автор робить акцент на системі, яка з самого початку не містила яскраво виражених ціннісних ідей, адже не враховувала особистісного аспекту. Але нині в межах системної методології освіту розглядають як багаторівневий простір із можливостями дослідження процесів, що відбуваються в ньому, і іï соціально-ціннісної ролі, яка зростає в період переходу від інформаційного суспільства до суспільства знань. При цьому, як один із визначальних чинників розвитку суспільства, освіта активно взаємодіє з іншими підсистемами й суспільством загалом. Соціально-культурологічний аналіз освіти як системи сприяє усвідомленню того, що вона володіє всіма ознаками (цілісністю, цілеспрямованістю функціонування, ієрархічністю і складністю будови, вірогідним характером стану й поведінки, здатністю до самоорганізації) такої системи, тому і освіту, і нову освітню парадигму вчені тлумачать у контексті найважливіших соціальних проблем взаємодії, в основі яких лежить неодмінна умова наукового пошуку аксіологічних ідей - свобода думки, не обмежена зовнішніми щодо науки умовами (Щедровицкий, 1998). Свобода думки - це варіант свободи вибору, а право й можливість свободи вибору обов'язкова категорія і в структурі особистості, і в сучасній парадигмі освіти.

Звертаючись до ідей Г. Ласуела і 3. Фрейда, науковці актуалізують трикомпонентний підхід до особистості, що відображає природу людини як відкритої системи, яка синтезує внутрішній і зовнішній план власного буття та, на 
їхню думку, є однією з методологічних підстав дослідження основ освіти. Саме трикомпонентну модель 3. Фрейда Г. Лассуелл проаналізував з точки зору соціальних процесів та виявив зв'язок окремих інституціоналізованих форм людської діяльності з конкретними особистісними процесами - свідомістю, цілепокладанням (структура «Я»), совістю («над-Я»); природженою схильністю, потягами («Воно») (Лассуэлл, 1994, с. 135-136). Освітня парадигма людського буття, реалізуючи принцип «потрійного впливу», одночасно розвиває доцільність, совість і вроджені потяги людини, тому може розглядатися універсумним складником цивілізаційного розвитку, оскільки освіта - це активність, потреба, діяльність, цінність, мета, засіб, результат, пов'язані з культурно зумовленим і соціально значущим процесом зміни можливостей особистості: «Освітня екзистенційність людської природи була усвідомлена вже 3 моменту становлення цивілізаційного способу буття людини, що включав у поняття «пайдейї» стан людини, яка реалізувала всі свої можливості духовного розвитку, стала особистістю в широкому значенні цього слова» (Лассуэлл, 1994, с. 135-136).

Історію розвитку цінностей в освіті представлено в монографії сучасної української вченої Н. Ткачової, основним завданням якої обрано дослідження ціннісних парадигм освіти в контексті євроінтеграції; у праці репрезентовано системне бачення сукупності освітніх цінностей, які, на думку авторки, є необхідними для вибору освітніх пріоритетів в українській системі освіти. У дослідженні вперше в педагогічній науці проведено системноретроспективний аналіз розвитку освітніх цінностей впродовж усієї історії існування людства, запропоновано їх переосмислення в контексті сучасних вимог суспільства (Ткачова, 2004, с. 201).

Принципово нову концепцію освіти як соціокультурного феномену розроблено у працях В. Огнев’юка (Огнев'юк, 2003, с. 189). За критерієм самоцінності освіти вчений систематизує основні цінності, які є підгрунтям сучасної освіти: культурні (свобода, творчість, любов, спілкування, діяльність); політико-правові (демократія, справедливість, закон і правопорядок); моральні (сенс життя, щастя, добро, відповідальність, обов'язок, совість, честь, гідність); національні (державність, традиції, мова); ключовими ж цінностями освіти вважає загальнолюдські - «добро», «істину», «любов», «свободу», «творчість» і «красу» (Огнев'юк, 2003, с. 124). Автором осмислено ціннісний потенціал і процеси зміни парадигм сучасної української освіти через дослідження цінностей сталого людського розвитку. До основних компонентів професійної освіти як соціального інституту В. Огнев'юк відносить відповідні галузі знань та властиву для освіти специфіку: сукупність форм людської діяльності; певну особливість відносин, що складаються між людьми в освіті; систему цінностей і норм у сфері освіти; специфічну мережу організацій, закладів і установ підготовки фахівців. На основі філософсько-аксіологічного осмислення освіти як однієї з найважливіших та всезагальних людських цінностей, іiї місця та ролі в системі цінностей сталого соціального розвитку, на який зорієнтовані трансформаційні процеси в нашій країні, ним доведено, що розвиток освіти завдяки постійному поверненню, кожного разу за інших умов, є лінійно поступальним процесом руху до наскрізних освітніх інваріантів - зразків, моделей, образів, установок тощо, особливе місце серед яких займають самобутні духовні цінності української культури.

С. Клепко питання цінностей освіти розглянув у онтологічній площині, висвітливши проблему за критерієм і засобом упорядкування й систематизації «цінностей буття»; провідними регулятивними цінностями освіти вчений інтерпретував «любов як спосіб виконання цінностей» та транснаціональне узгодження «старих» $\mathrm{i}$ «ових» соціальних цінностей з цінностями буття (Клепко, 2003).

В. Крижко основну увагу в площині аксіології професійної освіти надає освітнім системам. На думку вченого, згідно формули «педагог - це експерт із запровадження цінностей» особливого сенсу набуває необхідність аксіологічних корекцій управління освітою як соціальною інституцією, що зумовило розгляд ним аксіологічної парадигми в онтологічній генезі та поліпарадигмальному полі (Крижко, 2005, с. 231). Учені постійно наголошують: у сучасній освіті неминуче враховується, що людина здатна об'єктивувати свої потенціали, знання, уміння у вигляді предметів, а також зробити об'єктом власного розгляду своє і чуже мислення, психічні акти, прояви внутрішнього світу, хоча саме існування людини - це «відкрита можливість», базовою ознакою якої є здатність до вибору. Таке розуміння долає обмеження логіки лінійного спрямування кінцевої моделі розвитку та пропонує його циклічну модель, у якій не існує фіксованого кінцевого стану системи у вигляді останньої (вищої) стадії іiі розвитку, а відбувається неперервний процес транзитивного функціонування й переходу одного стану в інший. Організовуючи середовище своєї життєдіяльності, постійно вирішуючи важливі для неї проблеми, людина витрачає свою розумову, емоційну, фізичну енергію і створює при цьому свій світ буденності (життєвої і професійної) як певний акт винаходу, що водночас $\epsilon$ результатом здібностей особистості до самостворення, яким людина реально чи потенційно володіс.

Подолання поверховості розуміння освіти лише як засобу досягнення мети (інструментальний підхід) вимагає усвідомлення індивідом того, що освіта - це його проявлена сутність, практика себе, і те, які завдання в освіті ставить індивід, закладає основу його проекту себе. Процес оволодіння знаннями і становлення особистості має відносний характер, і з цієї причини сфера освітніх практик більше за інших відкрита для творчості і запозичення ідей різних соціокультурних систем. У цьому контексті метафорою освіти може бути, за словами I. Утюж, образ «міксера» («що перемішує» шари), який охоплює процес змішування різних історичних традицій, цінностей, уявлень, переваг, особливостей сприйняття та інших компонентів ментальності, унаслідок чого народжується новий тип менталітету, що закріплюється послідовністю трансформацій «аксіологічної спіралі»: менталітет-освітаменталітет (Утюж, 2013b, с. 40).

Учені звертають увагу на те, що в сучасних умовах проблема становлення особистості в контекстах професійної освіти активно й різнобічно розробляється і філософською антропологією, і соціальною філософією, які доводять, насамперед, необхідність і незамінність філософського умогляду в освіті, оскільки розуміння буття особистості як унікальної системи доступне тільки філософському осмисленню, а варіативність освітнього середовища дозволяє вчитися застосовувати при вирішенні поставленого завдання весь набір відповідних прийомів, починаючи 3 адаптивного й закінчуючи смислоутворювальними, інтелектуальними стилями, синтезувати нові знання, 
усвідомлювати переваги ментально-особистісного потенціалу та вчитися будувати діалог 3 іншими. Розуміючи людське суспільство як соціальне та культурне середовище, в якому особистість живе, функціонує, розвивається, визначає свої ціннісні орієнтації, бо перебуває з ним у двосторонніх відносинах прямого і зворотного зв'язку, існує можливість зосередитися на розгляді проблеми відносин особистості і суспільства, особистості й освіти, особистості і цінностей майбутньої професії. Культурний складник людського буття виражається передусім у провідному значенні антропологічного принципу, покладеного в основу професійної гуманітарної освіти людиноцентризму. Це зумовлено тим, що така освіта соціокультурно антропологічно детермінована; вона аксіологічна за своєю природою, тобто самоцінна, формує ціннісні пріоритети особистості й суспільства (Утюж, 2013b, с. 41).

Філософсько-антропологічна традиція орієнтує на загальнолюдські духовні цінності, ціннісні орієнтації, вартісну вважає думку про цивілізаційну природу освіти та прагнення до ціннісної регуляції. Об'єднуючи погляди мислителів на феномен духовності як культурну цінність особистості, освіта розвиває ті властивості особистості, які дозволяють їй бути творцем своєї життєдіяльності, правильно розуміти й перетворювати навколишню дійсність (Фромм, Шелер, Ясперс), актуалізує ціннісну основу, відповідно якої проходить самовизначення особистості, вибудовування ії внутрішнього світу, культурного простору, здійснюється вибір цінностей, цілей, смислів, розвиток духовних потреб у пізнанні, самопізнанні, рефлексії, зростає ціннісний шар свідомості. У такому шарі інтегруються вищі цінності, формується моральна стійкість особистості як форма самосвідомості, виникає самоідентифікація як підгрунтя для конструювання особистості в ролі суб'єкта, підвищується готовність до морального самовизначення в складних життєвих ситуаціях (Утюж, 2013b). За вихідний принцип при цьому беруть те, що сучасна особистість, будучи «просвітленою» освітою істотою, мусить освоювати необхідні ій знання, достатні для того, щоб творити власне буття. Водночас саме особистість розглядають домінуючою цінністю української професійної освіти.

У вітчизняній філософсько-освітній думці вважають, що особистість із самого початку $\epsilon$ істотою соціокультурною, а тому потребує освіти; не менш важливою - ідею про потребу особистості у прагненні до освіти. Аксіологічний аспект сучасної професійної освіти, особливо - гуманітарної - відображає потребу людини у визначенні для себе ціннісних пріоритетів пізнання; це пов'язане зі змінами нормативного розуміння сучасної особистості з точки зору цінностей свободи, відповідальності, самореалізації, з розвитком багатоманітної творчості, з реалізацією ідеї внутрішнього саморозвитку особистості і створення нею власного освітнього та компетентнісного професійного простору. Саме осмислення й перетворення ідеї внутрішнього саморозвитку особистості та створення нею власного освітнього простору пов'язане зі змінами традиційних уявлень про освіту як систему знань і вмінь, із дослідженням освіти як засобу самореалізації особистості, іiї цілей, відносин, мотивації. Ідея внутрішнього саморозвитку особистості сприяє їі смисложиттєдіяльності, а водночас - вирішенню технологічно зорієнтованих проблем культури й освіти, поєднаних із формуванням ціннісних пріоритетів, залученням до культури й відповідних цінностей. У цьому плані актуальним вважають перехід до такої сучасної парадигми, яка б домінуючому інтелектуалізму інформаційного суспільства протиставила особистісну концепцію в освіті, наблизилася б до ідеалів суспільства знань. А. Ахієзер переконує: усі культури тотожні в тому сенсі, що жодна 3 них не може бути реалізованою без творчих інновацій індивіда, який несе в собі потенціал відкритості, а освоєння культури можливе лише через культивування особистістю своєї творчої здатності (Ахиезер, 2007).

Процес виробництва нових знань, що грунтується на вже наявних, дає системі освіти перспективні можливості: вона сама створює необхідний суспільству освітній ресурс і активно впливає на життєвий рівень суспільства. Характерними ознаками освіти, яка відображує постмодерністську картину суспільства, є: співіснування безлічі концепцій, неоднозначність інтерпретації результатів, зближення наукових та ненаукових форм пізнання; знаходження в центрі уваги проблеми буття особистості та суспільства в їх ціннісному вимірі; ставка на знання як на засіб збереження, відтворення і розвитку культури, а не як спосіб задоволення потреб соціально-виробничої практики або чистої науки (Утюж, 2013b). Людська історія, що існувала для кожного, хто приходить у цей світ, на рівні буденності, безперервна і відокремлюється від життєвого потоку логікою пізнання.

Професійна гуманітарна освіта, включаючись у соціокультурні відносини як систему більш високого рівня інтеграції, піддається впливу соціокультурних змін, що зумовило необхідність ії цивілізаційного бачення через культуру, котра, входячи до процесу самопізнання і формуючи цивілізацію, виявляє свою транзитивну значущість в особистісних модальностях буття майбутніх фахівців. Культура метою освіти має виявлення людської сутності, яка щоразу відкривається перед новонародженою людиною, тому здатність професійної освіти розвивати людину $є$ провідною властивістю цивілізації; саме зв'язок освіти із життям виокремив М. Шелер, пропонуючи класифікацію форм знань залежно від їхньої включеності до процесів життєдіяльності людини (Шелер, 1994). Тому в цивілізаційній традиції реформування освітніх практик завжди пов'язане з моделюванням образу людини, а сучасні вчені транзитивність соціокультурного та цивілізаційного змісту професійної освіти визначають як їх поєднуваність і взаємоперехідність у способи цивілізаційно-культурних змін людини, іiі розвитку як особистості, головною властивістю якої є зорієнтованість на усвідомлення світу через осягнення самої себе, своїх потенціалів та реалізацію у процесі перетворювальної діяльності професійно ціннісних орієнтацій.

Аксіологія як наука про цінності відіграє роль орієнтира та регулятора педагогічних процесів і педагогічної діяльності, формує особистісне ставлення до них. У психолого-педагогічній літературі існують різні підходи до визначення понять «цінність», «ціннісні орієнтації»; переважно це пояснюється суб'єктивною позицією дослідників. Результати аналізу психолого-педагогічної літератури дають підстави стверджувати, що важливими компонентами особистісного самовдосконалення і саморегуляції у система професійної освіти вважають цінності й ціннісні орієнтації, враховуючи подвійну характеристику цінностей, зумовлену їх смисловою природою, що нами вже охарактеризовано вище. Саме смисл є основою для пізнання світу, спрямовує й активізує діяльність людини, тому професійні цінності визначають як елементи когнітивної структури особистості і як елементи ії мотиваційної сфери.

Професійні ціннісні орієнтації не мають однозначного трактування; їх розглядають як усвідомлені переконання чи уявлення суб'єкта про цінне для нього в обраній професії (Леонтьев, 1996, с. 21), як своєрідну форму існування 
цінностей. Співвідношення між такими цінностями і ціннісними орієнтаціями визначають як проблему розбіжностей між декларованими й реальними цінностями (Д. Леонтьєв). Реальні цінності можна співвіднести 3 поняттям «ціннісні орієнтації», адже саме ціннісні орієнтації стимулюють рух людини в певному напрямі, визначають вектор руху думки і дій. Погоджуємося $з$ думкою В. Ядова про те, що цінності реалізуються в ціннісних орієнтаціях і є елементом структури особистості (Ядов, 2007). Ціннісні орієнтації як форма функціонування цінностей знаходять відображення в професійних ідеалах, принципах, цілях, нормах життя і діяльності, потребах, загалом у тому складникові культури людини, який називають професійним.

Традиційно у психології виділяють такі структурні компоненти особистості: цінності індивіда, які є головними психічними утвореннями для визначення цілей активності особистості, образ «Я», ідеал, рівень намагань, самооцінка і самоконтроль. Ці компоненти можуть бути визначені як система саморегуляції особистості, у якій функція забезпечення активності людини реалізується тільки в процесі взаємодії цих компонентів. Введення блоку професійних цінностей до моделі саморегуляції особистості зумовило необхідність зважати на ії власні процеси цілевизначення на особистому рівні регулювання (Леонтьев, 1999), оскільки цінності розглядають основою для «народження» цілей саморегуляції особистості та іiі діяльності. Ціннісні утворення особистості функціонально пов'язані не тільки $з$ ідеалами, але й з таким структурним компонентом, як образ «Я» - уявлення про себе в професії. Образ «Я» в контексті саморегуляції особистості й професійної діяльності розглядають у співвідношенні 3 ідеалом. У процесуальному значенні уявлення про професійний ідеал («мені хотілося б») може «працювати» лише у випадку його зіставлення 3 уявленням людини про себе теперішнього - «хто я є». Реалістична розбіжність цих образів як внутрішня суперечність стимулює створення програми активності особистості, їі саморуху (Леонтьев, 1999), розвитку в процесі професійної освіти.

Висновки. Модернізація освітньої системи, зміна у зв'язку з цим професійних установок і цінностей на фоні відсутності чітко сформованих вимог до результатів діяльності, до професійних якостей, до процесу підготовки спонукають майбутніх фахівців постійно обирати між природним прагненням до стабільності фахових компетентностей і необхідністю руйнування старих уявлень, тобто зміною системи цінностей. Тому за результатами емпіричного дослідження, які детально буде представлено в дослідницькій перспективі, нами з'ясовано, що у багатьох майбутніх фахівців гуманітарної галузі не простежується механізм ціннісного вибору, ціннісного самовизначення; практика свідчить, що вони досить часто перебувають у стані «аксіологічної депресії» (термін А. Маслоу) (Маслоу, 1999). Особливості соціально-економічної ситуації, у якій здійснюється професійна діяльність, не можуть не впливати на зміну життєвих і професійних цінностей молоді, тоді як суспільство вимагає іншого професіонала, який може зважено приймати самостійні рішення та ефективно працювати в нестандартних умовах. Отже, проблема цінностей $є$ не тільки предметом наукових дискурсів, вона тісно пов'язана 3 суспільними процесами, системами професійної підготовки фахівців, культурою суспільства загалом.

\section{Список використаних джерел}

Андрущенко, В. П. (2008). Роздуми про освіту: статті, нариси, інтерв'ю. Київ: Знання України.

Ахиезер, А. С. (2007). Как открыть “закрытое общество”. Москва: Магистр.

Вязникова, Л. Ф. (2002). Ценности в образовании: выбор пути развития. Взято с //http://psyedu.ru/view .php?id=79.

Губерський, Л. В., Андрущенко, В. П., \& Михальченко, М. І. (2002). Культура. Ідеологія. Особистість: методологосвітоглядний аналіз. Київ: Знання України.

Клепко, С. Ф. (2003). Цінності буття і цінності освіти. Філософські обрї̈, 10, 260-271.

Крижко, В. В. (2005). Антологія аксіологічної парадигми освіти: навч. посіб. Київ: Освіта України.

Лассуэлл, Г.Д. (1994). Принцип тройного воздействия: ключ к анализу социальных процессов. Социологические исследования, 1, 135-143.

Леонтьев, Д.А. (1996). Ценность как междисциплинарное понятие: опыт многомерной реконструкции. Bопросы философии, 4, 15-26.

Леонтьев, Д. А. (1999). Психология смысла: природа, структура и динамика смысловой реальности. Москва: Смысл.

Маслоу, А. (1999). Новые рубежи человеческой природы. Москва: Смысл.

Огнев'юк, В. О. (2003). Освіта в системі цінностей сталого людського розвитку. Київ: Знання.

Ткачова, Н. О. (2004). Історія розвитку иінностей в освіті: монографія. Харків: ХНУ ім. В. Н. Каразіна.

Утюж, І. (2013а). Принципи постмодернізму в освіті. Гуманітарний вісник 3ДІА, 56, 63-72.

Утюж, І. (2011). Соціально-філософська інтерпретація аксіологічних ідей української освіти. Гуманітарний вісник ЗДІА, $44,38-42$.

Утюж, І. (2013b). Сучасні освітні парадигми: соиіально-філософський контекст : автореф. дис ... д-ра філос. наук : 09.00.03. Київ.

Щедровицкий, П. Г. (1998). “На повороте”. Курс лекций. Лекция 3. Институциональные изменения в сфере образования. Взято c http://vvww.uscr.citvline.ru/-ider;ast.

Андрущенко, В., \& Передборська, І. (Ред.). (2009). Філософія освіти: навч. посіб. Київ: НПУ імені М. П. Драгоманова. 
Шелер, М. (1994). Избранные произведения. Москва: Гнозис.

Ядов, В. А. (2007). Стратегия соичилогического исследования. Описание, объяснение, понимание социальной реальности. Москва: Омега-Л. Взято с https://www.isras.ru/publ.html?id=585.

\section{References}

Andrushchenko, V. P. (2008). Rozdumy pro osvitu: statti, narysy, interv'iu [Reflections on education: articles, essays, interviews]. Kyiv: Znannia Ukrainy [in Ukrainian].

Akhiezer, A. S. (2007). Kak otkryt “zakrytoe obshchestvo” [How to open a “closed society”. Moskva: Magistr [in Russian].

Viaznikova, L. F. (2002). Tcennosti v obrazovanii: vybor puti razvitiia [Values in Education: Choosing the Way of Development]. Retrieved from //http://psyedu.ru/view .php?id=79 [in Russian].

Huberskyi, L. V., Andrushchenko, V. P., \& Mykhalchenko, M. I. (2002). Kultura. Ideolohiia. Osobystist: metodoloho-svitohliadnyi analiz [Culture. Ideology. Personality: Methodological and philosophical analysis]. Kyiv: Znannia Ukrainy [in Ukrainian].

Klepko, S. F. (2003). Tsinnosti buttia i tsinnosti osvity [Values of being and the value of education]. Filosofski obrii [Philosophical horizons], 10, 260-271 [in Ukrainian].

Kryzhko, V. V. (2005). Antolohiia aksiolohichnoi paradyhmy osvity [Anthology of the axiological paradigm of education]: navch. posib. Kyiv: Osvita Ukrainy [in Ukrainian].

Lassuell, G. D. (1994). Printcip troinogo vozdeistviia: kliuch k analizu sotcialnykh protcessov [Principle of triple effects: the key to the analysis of social processes]. Sotciologicheskie issledovaniia [Sociological research], 1, 135-143 [in Russian].

Leontev, D. A. (1996). Tcennost kak mezhdistciplinarnoe poniatie: opyt mnogomernoi rekonstruktcii [Value as an interdisciplinary concept: the experience of multidimensional reconstruction]. Voprosy filosofii [Philosophy Issues], 4, 15-26 [in Russian].

Leontev, D. A. (1999). Psikhologiia smysla: priroda, struktura i dinamika smyslovoi realnosti [Psychology of meaning: nature, structure and dynamics of the semantic reality]. Moskva: Smysl [in Russian].

Maslou, A. (1999). Novye rubezhi chelovecheskoi prirody [New frontiers of human nature]. Moskva: Smysl [in Russian].

Ohnev'iuk, V. O. (2003). Osvita v systemi tsinnostei staloho liudskoho rozvytku [Education in the system of values of sustainable human development]. Kyiv: Znannia [in Ukrainian].

Tkachova, N. O. (2004). Istoriia rozvytku tsinnostei v osviti [History of the development of values in education]: monohrafiia. Kharkiv: KhNU im. V. N. Karazina [in Ukrainian].

Utiuzh, I. (2013a). Pryntsypy postmodernizmu v osviti [Principles of postmodernism in education]. Humanitarnyi visnyk ZDIA [ZDIA Humanitarian Bulletin], 56, 63-72 [in Ukrainian].

Utiuzh, I. (2011). Sotsialno-filosofska interpretatsiia aksiolohichnykh idei ukrainskoi osvity [Socio-philosophical interpretation of the axiological ideas of Ukrainian education]. Humanitarnyi visnyk ZDIA [ZDIA Humanitarian Bulletin], 44, 38-42 [in Ukrainian].

Utiuzh, I. (2013b). Suchasni osvitni paradyhmy: sotsialno-filosofskyi kontekst [Modern educational paradigms: socio-philosophical context]. (Extended abstract of D diss.). Kyiv [in Ukrainian].

Shchedrovitckii, P. G. (1998). "Na povorote" [On the turn]. Kurs lektcii. Lektciia 3. Institutcionalnye izmeneniia v sfere obrazovaniia. Retrieved from http://vvww.uscr.citvline.ru/-idcr;ast [in Russian].

Andrushchenko, V., \& Peredborska, I. (Red.). (2009). Filosofiia osvity [Philosophy of education]: navch. posib. Kyiv: NPU imeni M. P. Drahomanova [in Ukrainian].

Sheler, M. (1994). Izbrannye proizvedeniia [Selected works]. Moskva: Gnozis [in Russian].

Iadov, V. A. (2007). Strategiia sotciologicheskogo issledovaniia. Opisanie, obiasnenie, ponimanie sotcialnoi realnosti [Strategy of sociological research. Description, explanation, understanding of social reality]. Moskva: Omega-L. Retrieved from https://www.isras.ru/publ.html?id=585 [in Russian].

\section{VINNICHUK R.}

Poltava V. G. Korolenko national pedagogical University, Ukraine

\section{PEDAGOGICAL AXIOLOGY IN THE CONTEXTS OF HUMANITARIAN PROFESSIONAL EDUCATION}

The article describes the interpretation of pedagogical axiology in the context of humanitarian vocational education as a modern scientific direction of search of civilization guidelines for the professional development of a specialist. It is elucidated in the course of the characteristics of pedagogical axiology as a science of values, the notion of value orientations, their structure and classification, the possible ways of developing the personality axiom in humanitarian vocational education, which, from the axiological point of view, within the framework of the system methodology of education are regarded as multilevel space, one of the defining factors of a society that plays an active social and value role, and within the 
framework of the post-classical scientific paradigm - persistently actualises the axiological aspects of human existence (in general human and professional values and relevant value orientations and ideals).

Ukrainian scholars (teachers, psychologists, philosophers, sociologists, lawyers) pay particular attention to: the study of the value paradigms of vocational education in the contexts of European integration, the freedom to choose the systemic vision of the totality of humanitarian educational values. They comprehended the value potential and processes of changing the paradigms of modern Ukrainian education through the study of the values of sustainable human development; it is proved that the development of education is a linear progressive process of movement towards cross-cutting educational invariants - samples, models, images, installations, etc., a special place among which occupy original spiritual values of Ukrainian culture; the need for axiological corrections in the management of education as a social institution was explained, which led to the consideration of the axiological paradigm in ontological genesis and polyparadigmal discourse; The necessity and indispensability of the philosophical speculation in education - the understanding of the existence of the individual as a unique system, in which the variability of the educational environment allows us to use the whole set of appropriate techniques from the adaptive to the semantic and intellectual styles, to synthesize new knowledge, to realize the benefits of mental-personal potential and learn to build a dialogue with others.

By combining the views of thinkers on the phenomenon of spirituality as the cultural value of the individual, valueoriented education develops those properties of the individual that allow him to be the creator of his life, correctly understand and transform the surrounding reality, actualizes the value basis, respectively, self-determination of the individual, the construction of his inner world, cultural space, the choice of values, goals, meanings, development of spiritual needs in cognition, self-knowledge, reflection is carried out.

Key words: pedagogical axiology; humanitarian education; universal values; professional values; value orientations; value consciousness layer

Стаття надійшла до редакції 24.08.2019 р.

УДК 378.016:62/64(477)

DOI: https://doi.org/10.33989/2075-146x.2019.24.194601

ВЯЧЕСЛАВ ВОЛОСЬКИЙ

ORCID ID 0000-0001-6915-2692

Полтавський національний педагогічний університет імені В. Г. Короленка

\title{
ВІТЧИЗНЯНИЙ ДОСВІД ВИВЧЕННЯ ТЕХНОЛОГІЧНОГО ПРАКТИКУМУ
}

\begin{abstract}
У статті проаналізовано досвід вивчення дисципліни «Технологічний практикум» у процесі підготовки майбутніх учителів трудового навчання. Обгрунтовано, що вивчення «Технологічного практикуму» забезпечує міцний зв'язок між теоретичними знаннями студентів і їх практичною предметно-перетворювальною діяльністю. Встановлено міжпредметні зв'язки «Технологічного практикуму» з прикладними дисциплінами, які сприяють розвитку технічних творчих здібностей.

Розкрито основні завдання, які передбачає курс вивчення «Технологічного практикуму», зокрема: формування у майбутнього вчителя трудового навчання знань та вмінь необхідних для проведення уроків у школі; виховання добросовісного ставлення до праці, трудолюбства та дбайливості; навчитися розробляти та використовувати технічну документацію на вироби, що виготовляються для реалізації проектно-технологічної діяльності; розвиток творчих здібностей студентів; ознайомлення студентів із сучасними високопродуктивними способами обробки конструкційних матеріалів i організацією праці у навчальних майстернях.
\end{abstract}

Ключові слова: технологічний практикум; навчальна дисципліна; навчальна програма; вітчизняний досвід; трудове навчання; технології

Постановка проблеми. Важливе місце у навчальному процесі підготовки майбутнього вчителя трудового навчання, відіграє його практична діяльність, яка грунтується на основі проходження технологічного практикуму в навчальних майстернях і спецкурсів практичного характеру.

Комплексність практикуму, який ведеться в майстернях із обробки деревини й інших конструкційних матеріалів, зумовлена цілями і завданнями підготовки майбутнього вчителя трудового навчання для сучасної школи.

Аналіз останніх досліджень та публікацій. Проблемі практичної підготовки майбутніх учителів трудового навчання була предметом дослідження багатьох вітчизняних вчених, серед яких Р. Гуревич, Й. Гушулей, О. Коберник, М. Корець, В. Кузьменко, П. Лузан, В. Мадзігон, І. Мегем, В. Моштук, Л. Пташнік, В. Сидоренко, Г. Терещук, В. Титаренко, Д. Тхоржевський, А. Цина, М. Янцур, С. Ящук та інші.

Мета статті. Проаналізувати вітчизняний досвід вивчення технологічного практикуму в педагогічних університетах України.

Виклад основного матеріалу. На заняттях 3 «Технологічного практикуму» здійснюється підготовка майбутнього вчителя трудового навчання. Відповідно до навчального плану практикум, що охоплює ручну та механічну обробку конструкційних матеріалів, проводиться з першого дня навчання студентів у закладах вищої 